\title{
Speech Act Analysis of O. Henry's Short Stories and Implementation of the Integrated Teaching and Learning Process
}

\author{
Yanwar, A. P. ${ }^{1}$ \\ ${ }^{1}$ Universitas Bojonegoro, Bojonegoro, Indonesia \\ Corresponding email: amandapradhani2@gmail.com
}

\begin{abstract}
The teaching and learning process currently has an influence on students, especially the methods and the sources of the materials the teacher uses. The teacher can use various sources; for example, short stories, the use of which should be based on student needs. O. Henry's short stories were analysed in this research as they are interesting and having moral values that can be useful for students. O. Henry was chosen because his short stories are suitable for the teaching and learning process. Classes of speech acts can be found in them: representatives, directives, commissives, expressives and declaratives. In the teaching and learning process, teachers need to integrate skills with each other. It is also explained in further detail how O. Henry's short stories can be used to integrate reading and writing skills. Students need to integrate skills in order to be able to master them. In the paper, speech act analysis is made of O. Henry's short stories and implementation of the integrated teaching and learning process is discussed.
\end{abstract}

Keywords: Speech act, integrated teaching, and learning process 


\section{INTRODUCTION}

An effective teaching and learning process is very important for teachers and students. According to Coe, Aloisi, Higgins, and Major (2014), effective teaching is a process that leads students to have high achievement in valued outcomes (p. 9). Leadership and Teacher Development Branch (2005) states that professional learning can be the key to ensuring that schools can become learning communities where teachers work together, learn from each other, and share best practices on effective teaching and learning (p. 13). It also states that effective learning focuses on developing the core attributes of an effective teacher. It improves teachers' understanding of the content they teach and equips them with a range of strategies that enables students to learn this content (p. 4).

Nowadays, the methods and sources of the materials teachers use will have an influence on students. Students need to study in effective ways so that they can achieve what is needed by the end of the learning process. They also need to integrate skills so that they can master them well. According to Oxford (2001), there are two types of integrated skill instruction: content-based and task-based language instruction. Content-based instruction stresses learning content through language, while task-based instruction emphasises the performance of tasks that involve communicative language use. Oxford also states that the integrated skill approach introduces English language students to authentic language and challenges them to interact naturally when using the language. In addition, Oxford explains that the integrated skill approach allows teachers to ensure students progress by using multiple skills at the same time. Integrating language skills also promotes the learning of real content, not just the dissection of language forms.

Nowadays, teachers do not use interesting techniques or materials during the teaching and learning process, which means students do enjoy or feel engaged in the learning process. Khan and Ghosh (2016) argue that superior teaching stimulates students to learn and perform at least as expected, while poor teaching reduces students' interest in the learning topic, which can lead to poor performance. According to Adunola, as cited in Muema, Mulwa, and Mailu (2018), the poor academic performance by most students in various subjects is connected to the implementation of ineffective teaching methods used by teachers. Based on the discussion above, the writer intends to conduct a study entitled Speech Act Analysis of O. Henry's Short Stories and Implementation of the Integrated Teaching and Learning Process.

Teachers can use various material sources; for example, short stories, the use of which should be based on student needs. Pardede (2011) contends that these can be one of the most suitable choices in language teaching to help students to improve the four skills (listening, speaking, reading and writing) more effectively because of the motivational benefit embedded in them (p. 14). Collie and Slater (1991) state that there are four advantages of using short stories for language teachers: 1) they are practical, as their length means they can be covered in one or two class sessions; 2) they are not complicated for the students to work on by themselves; 3) they have a variety of choices for different interests and tastes; and 4) they can be used at all levels (beginner to advanced), all ages (young learners to adults) and in all classes 
(morning, afternoon or evening). Murdoch (2002) also states that if the teacher can select appropriate short stories, they can provide quality text content that will enhance ELT courses for students at intermediate level (p. 9). In this study, O. Henry's short stories were analysed because they are interesting and have moral values that can be useful for students. In addition, they are suitable for the teaching and learning process.

There are many aspects that can be learned from short stories, including speech acts. According to Yule (2006), these involve actions through performances, such as apologies, complaints, compliments, invitations, promises or requests (p. 47). Altikriti (2011) states that speech acts are related to how speakers use the language to perform intended actions and how listeners understand the intended meanings ( $\mathrm{p}$. 1374). Toolan (1997) also explains that speech acts refer to what is done when something is said (p. 250). Searle (1965) contends that there are five types of speech act: 1) representatives, which commit the speaker to the truth of the expressed proposition - for example, asserting or concluding; 2) directives, which refer to an attempt by the speaker to make the addressee do something - for example, requesting or questioning; 3) commissives, which commit the speaker to future courses of action - for example, promising, threatening or offering; 4) expressives, which refer to the expression of a psychological state - for example, thanking, apologising, welcoming or congratulating; and 5) declarations, which mean effecting immediate changes to the institutional state of affairs and tend to rely on elaborate extra-linguistic institutions - for example, excommunicating, declaring war, christening or firing from employment. In addition, Yule (2006) states that there are five types of general functions performed by speech acts (p. 53):

1. Declarations

These kinds of speech act change the world through utterances. For example:

a. Priest: I now pronounce you husband and wife.

b. Referee: You're out!

c. Jury Foreman: We find the defendant guilty.

2. Representatives

These speech acts state what the speaker believes to be the case or not. For example:

a. The earth is flat.

b. Chomsky didn't write about peanuts.

c. It was a warm sunny day.

3. Expressives

These kinds of speech act state what the speaker feels. For example:

a. I'm really sorry!

b. Congratulations!

4. Directives

These speech acts are used by speakers to get someone else to do something. For example:

a. Gimme a cup of coffee. Make it black.

b. Could you lend me a pen, please?

c. Don't touch that. 
5. Commissives

These are speech acts used by speakers to commit themselves to some future actions. For example:

a. I'll be back.

b. I'm going to get it right next time.

c. We will not do that.

The five types of speech act are summarised in Table 1 (Yule, 2006, p. 55).

Table 1. Five types of speech act

\begin{tabular}{llll}
\hline No. & Type of speech act & Direction of fit & \multicolumn{1}{c}{$\begin{array}{l}\text { S = speaker; } \\
\text { X = situation }\end{array}$} \\
\hline 1. & Declaration & words change the world & S causes X \\
2. & Representative & make words fit the world & S believes X \\
3. & Expressive & make words fit the world & S feels X \\
4. & Directive & make the world fit words & S wants X \\
5. & Commissive & make the world fit words & S intends X \\
\hline
\end{tabular}

Two previous studies are related to this research. The first was that of Alfiana (2009) entitled "Speech Act Analysis on Hello Magazine's Short Stories published in November 2008 - March 2009." The study found that the speech acts used in short stories in Hello magazine were representative, expressive, directive and commissive. There is one similarity and various differences between Alfiana's research and this. The similarity is that the two studies analyse speech acts used in short stories. On the other hand, there are three differences . First, Alfiana's research focused on speech acts used in Hello magazine short stories, while this research focuses on speech acts used at O. Henry's short stories. Second, this research also focuses on the use of O. Henry's short stories in the integrated teaching and learning process, while Alfiana's research did not do this. Third, the speech acts found in the short stories in Hello magazine were representative, expressive, directive and commissive, while those used in O. Henry's stories are declarative, representative, expressive, directive and commissive.

The second study was that of Trisnawati (2012), entitled "Empowering literature for educating character building (A study case on readers of O. Henry's After Twenty Years)." This found that After Twenty Years by O. Henry could be utilised to empower the teaching and learning process of character-building education. There is one similarity and two differences between this research and that of Trisnawati. The similarity is that both studies focus on the literary works of $\mathrm{O}$. Henry. On the other hand, the differences are that first, this research focuses on speech acts used in O. Henry's short stories, while that of Trisnawati does not do this. Second, this research also focuses on the use of O. Henry's short stories in the integrated teaching and learning process, while Trisnawati's research is centred on the use of After Twenty Years in character building education. 


\section{RESEARCH METHOD}

The study used a descriptive qualitative method. Sukmadinata, cited in Tajri (2013), states that such research is used to describe real circumstances, while Moleong (2000) contends that it is a type of research that does not include any calculation or enumeration (p. 32). The object of the study was speech acts used in O. Henry's short stories, with data comprising the dialogues between characters. Two steps were employed to collect the data:

1. Reading the stories.

2. Identifying the kinds of speech act used in them.

After identifying the types of speech act, those that could be implemented in the teaching and learning process were considered. They could also be used in the integration of skills; for example, reading, speaking and writing.

\section{FINDINGS AND DISCUSSION}

The study aimed to analyse different types of speech act in three O. Henry short stories (The Gift of the Magi, The Cop and the Anthem and The Furnished Room).

1. The Gift of the Magi

Types of speech act found:

a. Representative:

1. My hair grows awfully fast.

2. It's Christmas Eve, boy.

3. My hair grows so fast, Jim!

b. Directive:

1. Take your hat off and let's have a look at it.

2. Give it to me.

4. Please God, make him think I am still pretty.

5. Don't look at me that way.

6. Say 'Merry Christmas!' Jim, and let's be happy.

7. Cut it off and sold it.

8. Don't make any mistake about me, Della.

9. Be good to me.

10. Give me your watch.

11. Let's put our Christmas presents away and keep them for a while.

c. Commissive:

1. It'll grow out again.

d. Expressive:

1. Oh, oh!

2. The Cop and the Anthem

Types of speech acts found:

a. Directive:

1. Get busy and call a cop.

2. And don't keep a gentleman waiting.

3. Come along.

b. Declaration: 
1. "Three months on the Island," said the Judge to Soapy the next morning.

3. The Furnished Room

Types of speech act found:

a. Representative:

1. It's a nice room.

2. Yes, sir, this is the part of the city where theater people live.

3. She was a pretty little girl.

4. She had a sweet little face, Mrs. Purdy.

b. Directive:

1. Come in.

2. Tell me about Mrs. Mooney.

3. Do fill up your glass again, Mrs. McCool.

The types of speech act found in the three short stories are summarised in Tables 2-4.

1. The Gift of the Magi

Table 2. Types of Speech Act Found in The Gift and The Magi

\begin{tabular}{llll}
\hline No. & Type of Speech Act & Sentences & Percentage \\
\hline 1. & Representative & 3 & $8.33 \%$ \\
2. & Directive & 11 & $30.56 \%$ \\
3. & Commissive & 1 & $2.78 \%$ \\
4. & Expressive & 1 & $2.78 \%$ \\
5. & Declarative & - & $0 \%$ \\
6. & Common sentences & 20 & $55.56 \%$ \\
& & $\mathbf{3 6}$ & $\mathbf{1 0 0 \%}$ \\
\hline
\end{tabular}

2. The Cop and the Anthem

Table 3. Types of Speech Act found in The Cop and the Anthem

\begin{tabular}{llll}
\hline No. & Type of Speech Act & Sentences & Percentage \\
\hline 1. & Representative & - & $0 \%$ \\
2. & Directive & 3 & $13.64 \%$ \\
3. & Commissive & - & $0 \%$ \\
4. & Expressive & - & $0 \%$ \\
5. & Declarative & 1 & $4.55 \%$ \\
6. & Common sentences & 18 & $81.82 \%$ \\
& & $\mathbf{2 2}$ & $\mathbf{1 0 0 \%}$ \\
\hline
\end{tabular}

3. The Furnished Room

Table 4. Types of Speech Act found in The Furnished Room 


\begin{tabular}{llll}
\hline No. & Type of Speech Act & Sentences & Percentage \\
\hline 1. & Representative & 4 & $6.45 \%$ \\
2. & Directive & 3 & $4.84 \%$ \\
3. & Commissive & - & $0 \%$ \\
4. & Expressive & - & $0 \%$ \\
5. & Declarative & - & $0 \%$ \\
6. & Common sentences & 55 & $88.71 \%$ \\
& & $\mathbf{6 2}$ & $\mathbf{1 0 0 \%}$ \\
\hline
\end{tabular}

The results of the analysis show that the types of speech act are used differently in the three short stories. The first short story was The Gift of the Magi, with a total of 36 sentences. Four types of speech act were: representative $(8.33 \%)$, directive $(30.56 \%)$, commissive $(2.78 \%)$ and expressive (2.78\%). Common sentences $(55.56 \%)$ were also found in the story. The second short story was The Cop and the Anthem, with a total of 22 sentences. Two types of speech act were found in the story: directives (13.64\%) and declarations (4.55\%), with common sentences representing $81.82 \%$ of the total. The third short story was The Furnished Room, with a total of 62 sentences. Two types of speech act were found in this story: representative $(6.45 \%)$ and directive $(4.84 \%)$, together with $88.71 \%$ of common sentences.

Those three short stories can be used as teaching materials and be integrated between one skill and others; for example, between the teaching and learning of reading and writing skills. According to Kanwar, Shekhawat, Saxena, and Mehra (2017), integrated teaching refers to ways of connecting skills and knowledge from various sources and experiences, or implementing skills and practices in several settings. This means that integrated teaching bridges academic knowledge and practice. It provides many benefits and can be a main factor in conducting an effective educational programme. Therefore, integrated teaching can be very beneficial for students, who will enjoy the process more and be more engaged.

Worawuth, Prayuth, Kanokorn, Udomporn, Chadchawarn, and Wilawan (2014) argue that integrated learning is able to interest students more, enabling them to study with more enthusiasm and achieve higher scores. In developing integrated learning management, each teacher needs to have skill and experience in order to promote such learning. Worawuth et al. (2014) also state that students undertaking integrated learning are able to work better than lectured students. In addition, they explain that teachers must have appropriate skills, interest in integrated learning activities, and consistency. If they have sufficient skill and knowledge related to integrated learning, they can implement related activities during the teaching and learning process.

The quality of integrated English teaching is shown in the target, systematicness, normalisation, efficiency and effectiveness of the quality of integrated English teaching (Shi, 2016). Shi argues that more effective integrated English teaching comes from the joint functions of each component and the reasonable organisation 
of each teaching link, so that a good teaching quality assurance system is formed. Shi also states that the quality of integrated English teaching is limited by three factors, namely the teaching objective, the teacher and the students. Therefore, effective integrated English teaching can create a good teaching quality assurance system, supported by the teaching objective, teacher and students.

\section{CONCLUSION}

It is concluded that there are five types of speech act used differently in the three short stories of O. Henry: 1. The Gift of the Magi (representatives, directives, commissives and expressives); 2. The Cop and the Anthem (directives and declarations); and 3. The Furnished Room (representatives and directives). The remainder of the sentences can only be categorised as common sentences. In addition, these types of speech act can be implemented in the teaching and learning process. They can be used as integrated materials between one skill and others; for example, reading, speaking and writing. If integrated learning activities are implemented in the classroom, students will enjoy the process more and become more engaged. Finally, teachers must have sufficient skills and knowledge to be able to deliver good quality integrated English teaching.

\section{REFERENCES}

Alfiana, D. N. (2009). Speech acts analysis on Hello Magazine's short stories published in November 2008 - March 2009 (Thesis, Universitas Islam Negeri Sunan Ampel Surabaya, Surabaya, Indonesia). Retrieved from http://digilib.uinsby.ac.id/21973/

Altikriti, S. F. (2011). Speech act analysis to short stories. Journal of Language Teaching and Research, 2(6), 1374-1384.

Coe, R., Aloisi, C., Higgins, S., \& Major, L. E. (2014). What makes great teaching?: Review the underpinning research. Retrieved from http://www.suttontrust.com/wpcontent/uploads/2014/10/What-Makes-Great-Teaching-REPORT.pdf

Collie, J., \& Slater, S. (1991). Literature in the language classroom. (5th ed.). Glasgow: Cambridge University Press.

Kanwar, G., Shekhawat, M., Saxena, N., \& Mehra, M. C. (2017). Introduction and impact of integrated teaching learning method for first professional medical students. IOSR Journal of Research \& Method in Education, 7(1), 10-13.

Khan, A., \& Ghosh, S. K. (2016). Analysing the impact of poor teaching on student performance. Paper presented at International Conference on Teaching, Assessment, and Learning for Engineering, Bangkok, Thailand. Retrieved from https://www.researchgate.net/publication/313688697_Analysing_the_impact_of_poor_teachi ng_on_student_performance

Leadership and Teacher Development Branch. (2005). Professional learning in effective schools: The seven principles of highly effective professional learning. East Melbourne, Australia: Author.

Moleong, J. L. (2000). Metodologi Penelitian Kualitatif. Bandung, Indonesia: PT. Remaja Rosdakarya Press.

Muema, J. S., Mulwa, D. M., \& Mailu, S. N. (2018). Relationship between teaching method and students' performance in Mathematics in public secondary schools in Dadaab Sub County, Garissa County; Kenya. IOSR Journal of Research \& Method in Education, 8(5), 59-63.

Oxford, R. (2001). Integrated skills in the ESL/EFL Classroom. ERIC Digest 2002-2. Retrieved from http://www.ericdigests.org/2002-2/esl.htm

Pardede, P. (2011). Using short stories to teach language skills. Journal of English Teaching, 1(1), 14-27. 
Searle, J. R. (1965). "What is a Speech Act?" In Philosophy in America (Ed.), Pragmatics, Discourse Analysis and Socio Linguistics (pp. 221-239). London: Allen and Unwin.

Shi, Y. (2016). Research on integrated education mode in college English teaching. Paper presented at the International Conference on Information Technology \& Communication Engineering, Bangalore, India. Retrieved from https://www.shsconferences.org/articles/shsconf/pdf/2016/03/shsconf_icitce2016_01012.pdf

Tajri, Y. (2013). Pendidikan karakter Islami di sekolah. (Skripsi, Universitas Pendidikan Indonesia, Bandung, Indonesia. Retrieved from http://repository.upi.edu

Toolan, M. (1997). Working with text: A core book for language analysis. London: Routledge.

Trisnawati, R. K. (2012). Empowering literature for educating character building (A study case on readers of O. Henry's After Twenty Years). Journal of English and Education, 6(1), 53-65.

Worawuth, P., Prayuth, C., Kanokorn, S., Udomporn, K., Chadchawarn, A., \& Wilawan, P. (2014). Integrated learning teacher professional development in primary schools. Procedia - Social and Behavioral Sciences, 112, 775-780.

Yule, G. (2006). Pragmatics. New York: Oxford University Press. 